\title{
CHARIZMA A POSLANIE AUGUSTIÁNSKYCH KLÁŠTOROV V STREDOVEKU NA ÚZEMÍ DNEŠNÉHO SLOVENSKA
}

\author{
Charism and the Mission of Medieval Augustinian Monasteries \\ in the Area of Modern Slovakia
}

\author{
Miroslav Hut'ka
}

DOI: 10.17846/CL.2018.11.2.132-142

\begin{abstract}
HUŤKA, Miroslav. Charism and the Mission of Medieval Augustinian Monasteries in the Area of Modern Slovakia. In the Middle Ages, the mendicant order of Augustinians built four monasteries in the area of modern Slovakia, located on relatively compact territory in the historical regions of Spiš and Šariš - in Velký Šariš, Hrabkov, Bardejov and Spišské Podhradie. Two monasteries were in smaller towns - oppidum (Velký Šariš and Spišské Podhradie), while one was built in a larger town - civitas (Bardejov). The monastery in Hrabkov was situated in a rural environment. All of these monasteries were barely a day's journey away from each other. This study will try to answer following questions: What was the mission of these monasteries? What function did they perform? How did they fulfil their mission to spread the Gospel? What role did their affiliation play in their foundation? The main objective will be to clarify the particular assignment of the individual priorates. It seems that it was not just about pastoral duties; otherwise a monastery would not have been built in rural Hrabkov. What then was their function?
\end{abstract}

Keywords: Middle Ages, Slovakia, Mendicant Orders, Augustinians, activity

\begin{abstract}
Abstrakt: HUŤKA, Miroslav. Charizma a poslanie augustiniánskych kláštorov v stredoveku na území dnešného Slovenska. Žobravá rehola augustiniánov vybudovala v stredoveku na území dnešného Slovenska štyri kláštory, ktoré sa nachádzali na pomerne kompaktnom území historických regiónov Spiša a Šariša: vo Velkom Šariši, v Hrabkove, v Bardejove a v Spišskom Podhradí. Dva kláštory stáli v menších mestečkách - oppidum (Velký Šariš a Spišské Podhradie) jeden kláštor stál vo väčšom meste - civitas (Bardejova), no kláštor v Hrabkove stál $\mathrm{v}$ dedinskom prostredí. Všetky kláštory boli od seba vzdialené sotva jeden deň cesty pešo. V štúdii sa pokúsime nájst’ odpoved’ na otázky: Aké bolo poslanie jednotlivých kláštorov? Akú funkciu plnili? Ako napínali svoje poslanie šírit evanjelium? Akú úlohu pri ich vzniku zohrala filiácia? Hlavným cielom bude objasnit konkrétne poslanie jednotlivých priorátov. Zrejme nešlo len o pastoráciu, ved’ inak by nebol vybudovaný kláštor v rurálnom prostredí Hrabkova. Čo bolo teda náplňou ich pôsobenia?
\end{abstract}

Klúčové slová: stredovek, Slovensko, žobravé rehole, augustiniáni, činnost

Mestské kláštory žobravých reholí plnili nezastupitelnú kultúrno-spoločenskú a najmä náboženskú funkciu, v ktorej konkurovali hlavne mestským farárom. Z toho plynuli rôzne problémy, a to najmä v období krátko okolo vzniku príslušného kláštora, pričom mnohé musel riešit dokonca samotný pápež. Reálny život však bol zrejme omnoho pestrejší. Kláštory boli totiž aj hospodárskymi jednotkami, ktoré sa starali o bezproblémové zásobovanie, prestavby svojich objektov, o obchod 
a iné. Poslaním všetkých reholí však bolo predovšetkým šírenie evanjelia, duchovný rozvoj reholníkov a starostlivost' o náboženský život v ich okolí. Ciel’om tohto príspevku bude analýza pôsobenia augustiniánskej rehole v období stredoveku na území dnešného Slovenska so zvláštnym zretelom na oblasť Šariša a Spiša, kde sa nachádzali všetky štyri kláštory Rehole pustovníkov sv. Augustína. Aké boli vzájomné kontakty a väzby týchto nevelmi od seba vzdialených kláštorov? Ako spolupracovali alebo aké bolo ich špecifické pôsobenie v regióne? Ako sa starali o duchovný život veriacich v ich okolí? Prečo bol založený kláštor žobravej rehole v dedinskom prostredí? Na úvod je taktiež potrebné pripomenút, že sa jednalo o kláštory vo Vel'kom Šariši, v Hrabkove, v Bardejove a v Spišskom Podhradí.

Spracovanie témy dejín augustiniánov je už pomerne rozsiahle (Hutka 2013b, 190 nn.), no stále sa vynárajú nové otázky. Najstarším zo štyroch augustiniánskych kláštorov na území dnešného Slovenska bol Priorát sv. Stanislava vo Velkom Šariši. Jeho založenie sa však spája s pôsobením Rehole sv. Viliama v pohraničí Uhorska (Hutka 2013a, 143-158). Viliamiti boli jednou zo štyroch väčších reholí, ktoré boli v roku 1256 v tzv. Vel'kej únii zlúčené do novej rehole augustiniánov. Pôvodnou charizmou viliamitov bol život v ústraní naplnený prácou a modlitbou. Ich poslaním bola skôr polnohospodárska práca a kultivácia krajiny. Išlo totiž o pustovnícku reholu v duchu Reguly sv. Viliama z Malavalle. ${ }^{1}$ Preto možno celkom oprávnene pochybovat’ o tom, že sa pustovníci usadili pod významným hradom, v tesnom susedstve dynamicky sa rozvíjajúcej podhradskej osady. Kde sa však viliamiti pôvodne usadili nie je dnes známe, no toponým odvodených od pustovníkov je v Šariši viac ako dost'. Na základe donačnej listiny krála Ladislava IV. Kumánskeho z roku 1274 možno vyslovit hypotézu, že pôvodne mohli byt’ viliamiti usadení nedaleko krajinskej cesty hned' za pohraničnými zásekmi pod vrchom Michalka (dnes kóta 652,3) nedaleko Pečovskej Novej Vsi (MZA E4 inv. č. 5, sign. $41 \mathrm{~V}: 1$ ). Ešte aj dnes sa toto územie nazýva Mniše (Mnišske) a o jeho polohe hovorí aj reambulačná listina z roku 1322 (AO II 1881, 36; RDSI II 1987, 346-347). Toto územie bolo totiž súčastou královskej donácie presne ohraničené métami. Presun viliamitov, alebo po roku 1256 už lepšie augustiniánov, do miest nastal definitívne niekedy po roku 1266, ked' sa všetky viliamitské kláštory v Uhorsku a Nemecku stali súčastou rehole augustiniánov (Elm 1962, 89), ${ }^{2}$ ćím bola natrvalo potvrdená aj zmena charakteru a charizmy celej rehole transformáciou pustovníctva (Ordo eremiticus) na pastoráciu (Ordo apostolicus). Pápež Alexander IV. v bule „Licet Ecclesiae Catholicae“ v roku 1256 prikázal augustiniánom prestahovat sa do miest, kde mali pomáhat ludom na ceste k spáse (Empoli 1628, 18-20; Lujik 1964, 163; Roth 1953, 21; Andrews 2006, 86-87). Pôvodné poslanie sa tak definitívne zmenilo a augustiniáni už mali pôsobit pastoračne ako žobravá rehola. Na tento účel sa preto lepšie hodilo mesto ako „pustina“ (les). Usadenie sa augustiniánov (viliamitov) vo Velkom Šariši tak zrejme prebehlo niekolko rokov pred rokom 1274, ked’ bola vydaná listina krála Ladislava IV. Kumánskeho.

Pastoračná činnost̉ však kláštoru neprinášala dostatok finančných prostriedkov a reholníci údajne pre chudobu nemohli dôstojne žit'. Preto prior kláštora Štefan požiadal v roku 1285 krála Ladislava IV. o dalšiu donáciu tentoraz na dedinu Záhradné - Scegekerthe (MES II 1882, 199; CDH V/3 1830, 294). Konal tak zrejme ani nie ako predstavený kláštora žobravej rehole, ale skôr ako predstavený kláštora pustovníckej rehole. Je taktiež možné, že okolie neposkytovalo

1 Sv. Viliam z Malavalle bol pustovníkom na hore Monte Pisano odkial’ odišiel do údolia Stabbio di Rodi nedaleko Castiglione della Pescaia, kde v roku 1157 umrel. Jeho hrob sa stal vel'mi skoro pútnickým miesto a jeho život začal mat’ nasledovníkov. Rehola existovala do roku 1847, ked' bol zatvorený posledný kláštor v Huybergene v Holandsku a 3. augusta 1879 zomrel ostatný príslušník rehole, brat van den Berg.

2 Medzi rokmi 1256 - 1266 prebiehal spor augustiniánov s viliamitmi, ktorí sa odmietli podriadit príkazu o zlúčení oboch reholí a nad’alej viedli zápas o osamostatnenie, ktorý bol ukončený kompromisom z Viterba v roku 1266, no ich kláštory v Uhorsku a Nemecku zostali v rukách augustiniánov. 
mendikantom dostatok príležitostí, a tým aj prostriedkov k obžive, možno pre slabú ekonomickú rozvinutost'. Zároveň sa $\mathrm{v}$ tejto listine po prvýkrát objavuje aj patrocínium kláštora, ktorý bol zasvätený k úcte sv. Stanislavovi - monasterii S. Stanislai de Sár (CDH V/3 1830, 294).

Ďalším spôsobom, akým sa vel'košarišskí augustiniáni zapájali do života stredovekej spoločnosti v oblasti Šariša, bola administratívna a notárska funkcia. Kláštor vo Velkkom Šariši stál v centre župy, čo ho na túto úlohu priam predurčovalo. Išlo predovšetkým o funkciu tzv. hodnoverného miesta (locus credibilis), uhorskej obdoby notárskych úradov. Napríklad už v roku 1278 vystupovali ako svedkovia pri del'be majetku v blízkosti Červenice, na jednej strane medzi synmi Tekula (Tekuša?): komesom Tomášom a jeho bratmi Ledem (Ladislavom?) a Martinom a na druhej strane Andrejom synom Buduna (DCS 1780, 291-292; Beňko 1985, 203). V rámci delby majetku mala byt vyplatená suma 20 mariek striebra v prítomnosti bratov viliamitov Rehole sv. Augustína z Velkého Šariša (DCS 1780, 292; CDH V/2 1829, 432-434). Augustiniánsky prior Ján sa spomína ako svedok spísania testamentu Viliama Drugetha na Šarišskom hrade 9. augusta 1330 (MNL OL DL, 71270; Sedlak 2002, 99). ${ }^{3}$ V prítomnosti augustiniánov z Velkého Šariša sa riešil aj spor viacerých šlachticov, ktorý prejednával krajinský sudca a turčiansky župan Michal de Zich (Zeech) z roku 1357 (AO VI 1891, 549-550).

Je možné, že túto notársku funkciu kláštor vykonával až do obdobia rokov 1351 - 1353, ked' došlo $\mathrm{k}$ revízii pečatí a mnohé kláštory $\mathrm{v}$ Uhorsku túto funkciu stratili. No kláštor údajne vlastnil hodnovernú pečat ešte aj na začiatku 16. storočia (Hudáček - Uličný 2010, 557). S funkciou hodnoverného miesta súvisela aj skutočnost', že v kláštore mali uložené dôležité listiny mnohé šlachtické rody, ako napr. v roku 1341 Andrej Sakerdoš (CDH VIII/4 1832, 526; Hudáček - Uličný 2010, 557).

Hlavným poslaním rehole však bola pastorácia, a to platí aj o kláštore sv. Stanislava. Priame dôkazy o tom neexistujú, no s pastoráciou sa velmi úzko spája kňazské svätenie. Na tento účel mali augustiniáni zriadené provinčné štúdium napr. v Ostrihome, no najšikovnejší študenti odchádzali na univerzity do zahraničia. Jedným z takýchto študentov bol aj Ján z Velkého Šariša, ktorý v roku 1393 študoval vo Verone (Hutka 2016, 25).

Pustovníci sv. Augustína sú v uhorských stredovekých dejinách známi tiež ako vedúce osobnosti vnútornej aj vonkajšej katolíckej misie. Táto činnost’ vyplývala najmä z pastoračného poslania. Vnútornou misiou mohli byt poverené niektoré kláštory vybudované v centrálnej časti Uhorska. Napríklad priorát sv. Anny v Ostrihome, ktorý bol zriadený v arménskej časti mesta, podobne ako kláštor sv. Štefana Prvomučeníka na budínskom predmestí sv. Petra (Romhányi 2005, 93; Romhányi 2000, 16, 24). V stredovekom Uhorsku boli len dve lokality, kde sa spomínajú Arméni a v obidvoch boli vybudované kláštory augustiniánov (Romhányi 2005, 93). Celú túto problematiku je zrejme potrebné chápat’ $\mathrm{v}$ širšom kontexte, pričom mohlo íst’ o časti miest nielen $s$ arménskym obyvatel'stvom, ale aj s pravoslávnymi krestanmi.

No vnútornej misii sa venovali zrejme aj augustiniánske kláštory založené na území obývanom kumánskym obyvatel’stvom. Tomuto účelu zrejme slúžili kláštory založené v južnom a centrálnom Uhorsku: v Gătaia (Mezősomlyó), v Lórév, v Bátmonostor a možno vo Vacove. To by vysvetlovalo, prečo boli niektoré z nich lokalizované do riedko osídlených oblastí (Romhányi 2005, 93).

Zdá sa, že pri konverzii Kumánov významné miesto zastával augustinián sv. Vít z Panónie, ktorý prostredníctvom svojho kázania údajne obrátil na krestanskú vieru viac ako desattisíc Kumánov, z ktorých väčšinu sám vlastnoručne aj pokrstil. Tento údajne velmi cnostný, zbožný

V testamente boli menované cirkevné osobnosti v poradí podla dôležitosti. Na prvom mieste bol Peter prepošt premonštrátskeho kláštora v Nižnej Myšli, dalej opát kláštora v Krásnej nad Hornádom Ján, Jakub košický farár a až na štvrtom mieste brat Ján $z$ Velkého Šariša. Zaujímavostou je neprítomnost vyšších cirkevných predstavitelov alebo predstavitelov hodnoverných miest (Jasov, Leles alebo Spišská Kapitula). 
a horlivý muž napokon v roku 1297 umrel v povesti svätosti a jeho telo pochovali v augustiniánskom kláštornom Kostole sv. Anny v Ostrihome (Hutka 2012, 121-213). Augustiniáni ho v stredoveku uctievali ako svätého (Arbesmann 1966, 25-29), pričom ho Henrich z Friemar dokonca uvádza vo svojom zozname augustiniánskych osobností z roku 1334 na čestnom druhom mieste, hned' za jedným zo zakladatelov celej rehole augustiniánov sv. Jánom Bonusom - Bonom (Friemar 1909-1912).

Misia medzi Kumánmi však pokračovala aj v 14. storočí a zdá sa, že augustiniáni aj v tomto období pri konverzii hrali významnú úlohu. Známe je najmä pôsobenie Štefana z Ostrova (de Insula), augustiniánskeho reholníka z kláštora v Lórév na ostrove Csepel - preto z Ostrova alebo Szigeti (Udvárdy 1956, 334-335). Bol absolventom parížskej univerzity a držitel’ najvyššieho teologického titulu doktor svätej teológie. Pre jeho schopnosti ho 11 . januára 1350 pápež Klement IV. vymenoval za nitrianskeho biskupa (Vurum 1835, 268) a 10. februára 1367, po uprázdnení stolca v Kaloči, sa Štefan z Ostrova (známy aj pod menom Frankói) stal novým kaločským arcibiskupom (Theiner 1863, 250; Udvárdy 1956, 330). Angažoval sa nielen pri konverzii Kumánov, ale aj pri katolíckej misijnej činnosti v Bosne, Bulharsku a Valašsku, pri ktorej spolupracoval aj s františkánmi. Jeho pričinením, ako pápežského legáta, boli v tejto oblasti erigované postupne tri nové katolícke biskupstvá: v Severine (1376), v Argens (Curtea de Argeş - vzniklo vo Valašsku rozdelením severínskeho biskupstva, no existovalo velmi krátko 1381 - 1386) a vo Vidine (Udvárdy 1956, 334-335). V jeho práci mu pomáhali aj další dvaja augustiniáni bratia: Peter z Vrábel' a Mikuláš, obaja s vynikajúcim univerzitným vzdelaním z Paríža. Obaja pôsobili aj na královskom dvore ako kapláni (MVS II/1, 170; Udvárdy 1956, 327-328). V roku 1366 prišiel biskup Štefan z Ostrova do Avignonu a poprosil pápeža Urbana V., či by Petra z Vrábel' nechal preskúšat na avignonskej fakulte biskupom z Friual, spovedníkom Svätého Otca, a či by mu v prípade úspechu udelil titul magistra teológie. Údajne potreboval erudovaných ludí na boj proti schizmatikom (MVS II/1, 275).

Do kategórie misijných kláštorov pravdepodobne možno zaradit aj augustiniánske kláštory sv. Ducha v Hrabkove a sv. Jána Krstitela v Bardejove. Túto misijnú činnost však možno chápat’ len $\mathrm{v}$ širšom slova zmysle. Totiž, len vel’mi tažko sa hladá dôvod založenia augustiniánskeho kláštora v nevelkej dedine Hrabkov, vzdialenej sotva niekolko kilometrov (21?) od kláštora sv. Stanislava vo Velkom Šariši. Iste, dôležitým faktorom bola vôla donátora, no týmto tvrdením sa nedá vysvetlit celá problematika. Ako je známe, kláštor bol založený v roku 1334 komesom Mikulášom z Perína, ktorý ho aj patrične obdaroval (DCS 1780, 517-518; CDH VII/3, 712-713; Schier - Rosnák 1778, 71). Prítomnost̉ Herkeho z Vel'kého Šariša pri fundácii naznačuje filiáciu a možnú tesnú previazanost̉ oboch kláštorov, no účel sa stále nedá vysvetliț. Jednou z možností je skutočnost', že hrabkovský kláštor mohol slúžit ako „pustovnícke“ zázemie pre rehollníkov z Vel'kého Šariša, ktorí sa chceli obrátit k reholnému archetypu - eremitizmu. No kláštor sv. Ducha nestál na „pustom“ mieste! Vysvetlením by mohli byt udalosti z roku 1340. Mikuláš z Perína sa v tomto roku pokúsil v susednej dedine Križovany založit františkánsky kláštor. Na základe jeho žiadosti pápež Benedikt XII., poveril ostrihomského arcibiskupa zistit, či je objekt primerane vybavený pre potreby reholníkov a v prípade, že áno, má zabezpečit jeho prijatie do uhorskej františkánskej provincie (DCS 1780, 519-520; Rábik 2006, 115). Podla Mikulášových slov - na jeho majetku v Križovanoch žilo väčšie množstvo schizmatického obyvatel'stva rusínskej národnosti, možno z Haliče, ktorí boli pravdepodobne usadení v zaniknutej dedine *Vola severne od Križovian. Prítomnost' Valachov v tomto regióne už v 14. storočí je bezpečne doložená (Rábik 2006, 115). Prečo sa však Mikuláš v priebehu šiestich rokov pokúšal v susednej dedine Hrabkova fundovat nový kláštor, nie je jasné. Nebol spokojný s činnostou augustiniánov? Navyše možno predpokladat, že pravoslávni krestania sa v tejto oblasti dlho nezdržali, kedže zrejme išlo o pastierov (valachov), ktorí sa často presúvali. Je teda možné, že aj augustiniáni boli usadení v Hrabkove z dôvodu konverzie pravoslávnych pastierov, 
podobne ako františkáni v Križovanoch. No františkánsky kláštor zrejme nikdy nevznikol, pretože o ňom neexistujú iné písomné zmienky.

Pri donácii dediny Hrabkov, získali augustiniáni aj patronátne právo nad miestnym kostolom sv. Šimona a Júdu (DCS 1780, 518). Po tom, ako dedinu stratili a boli odškodnení v roku 1361 novou dedinou Chmiňany, takéto patronátne právo získali aj tu. No miestny Kostol sv. Štefana Prvomučeníka bol krátko pred týmto rokom zničený povodňou spolu s celou dedinou. Miestni obyvatelia preto začali navštevovat Kostol sv. Pavla v susednej dedine Chminianska Nová Ves, kde sa nechávali aj pochovávat. Miestnemu kňazovi (napríklad Jánovi) preto odvádzali aj jednu štvrtinu svojich cirkevných desiatkov. Nevedno, z akého dôvodu sa to augustiniánom z Hrabkova nepáčilo a stažovali sa pri jágerskom biskupovi Štefanovi, ktorý nariadil v roku 1395 celú záležitost’ vyšetrit' (ZsO I 1951, 461-462; Rábik 2006, 113). Komisia došla k záveru, že obyvatelia dediny Chmiňany majú platit cirkevný desiatok ako predtým. Augustiniáni však mali nadalej pocit, že im táto štvrtina patrí, a preto sa v roku 1461 opät stažovali. Spišská Kapitula však pri vyšetrovaní došla k rovnakému záveru, ako komisia jágerského biskupa (MNL OL DL 70259). Jedno z vysvetlení tohto sporu môže byt pastoračná snaha augustiniánov, ktorú však nemohli dôsledne vykonávat', kedže obyvatelia Chminian nadalej, aj po sto rokoch, navštevovali kostol v susednej dedine, kde mali pochovaných aj svojich blízkych.

Hypoteticky podobnú funkciu, ako hrabkovský kláštor, mohol plnit aj kláštor v Bardejove. V jeho prípade však možno uvažovat o pokuse (snahe) o konverziu pravoslávnej Haliče, o čo sa logicky staralo prevažne Pol’sko. O takejto činnosti bardejovských augustiniánov však nie sú žiadne správy. No existuje velavravná poznámka $v$ registri generálnych priorov o tom, že kláštor je situovaný na hraniciach s Haličou (Rutenorum) a so schizmatikmi (BV III 1999, 176-177).

V meste Bardejov však augustiniáni vykonávali aj skriptorskú činnost', o ktorej však vieme len vel'mi málo. Jedna z informácií pochádza z roku 1428, ked’ prior kláštora Izaiáš Boner vyslal dvoch bratov - pisárov, možno do Krakova, prepisovat knihy, ktoré boli určené pre jeho potrebu (Féjerpataky 1885, 286-287). Niektorí historici však pripisujú augustiniánske autorstvo aj v prípade niektorých iných rukopisov (Sopko 1980, 19-37). ${ }^{4}$

Augustiniáni v Bardejove vykonávali aj pastoráciu medzi veriacimi, na ktorú využívali aj rôzne bratstvá, ktoré začali byt populárne najmä od druhej polovice 15. storočia. Jedným z nich bolo aj Bratstvo blahoslavenej Panny Márie, ktoré existovalo pri augustiniánskom Kláštore sv. Jána Krstitela (Domenová 2006a, 206; Domenová 2006b, 19). Pomáhalo zrejme reholníkom pri ich práci $\mathrm{s}$ veriacimi v meste a zároveň dokazuje úctu $\mathrm{k}$ Božej matke, ktorá bola v reholi velmi živá.

Bardejovský kláštor sa spolu s kláštorom v Körmende spomína ako príklad mravného úpadku reholného života uhorských augustiniánov na konci stredoveku (Erdélyi 2004, 117-140). Existujú totiž nepriame dôkazy, ktoré to môžu naznačovat'. Ako príklad možno spomenút prísny tón listu vel'košarišského priora a vikára augustiniánov v jágerskej diecéze Ambróza z roku 1493 adresovaný bardejovskej mestskej rade. Nemenovaní bratia $\mathrm{v}$ ich kláštore žili hriešnym a očierňujúcim životom, čím opovrhli sv. Augustínom. Chystal sa príst’ do mesta a vyriešit celú záležitost' (DCS 1780, 532). Nevedno však, o čo išlo. Mohlo sa jednat’ o závažné porušenie disciplíny, no aj o menší prehrešok a prísny tón Ambrózovho listu bol len prejavom razantného postupu. Na druhej strane o dva roky došlo $\mathrm{k}$ dalšiemu incidentu v kláštore, ked’ spolubratia obvinili svojho predstaveného priora Baltazára z krádeže vecí, ktoré patrili kláštoru. Prior sa bránil pred mestskou radou, že obvinenia nie sú pravdivé, no priznal sa k odcudzeniu postel'nej bielizne (ŠA PO Bardejov, č. 3237;

4 J. Sopko pripisuje augustiniánom dva zachovalé graduály uložené v Univerzitnej knižnici v Budapešti, ktoré sú bohato zdobené farebnými ornamentálnymi iniciálami, vychádzajúcimi štýlovo z francúzskych výzdobných motívov. Oba kódexy sú však datované do prvej polovice 14. storočia, teda do doby, ked’ ešte kláštor v Bardejove neexistoval. 
Sroka 2011, 34; Jankovič 1975, 126). Podobný incident sa zopakoval aj v roku 1527, ked' bol prior Matej obžalovaný krakovskými augustiniánmi, že nevrátil 2 dalmatiky zlatej farby, za ktoré slúbil zaplatit peniazmi alebo vínom (Sroka 2011,37). Do akej miery však tieto poklesky reholníkov negatívne ovplyvňovali verejnú mienku, podobne ako tomu bolo v meste Körmende, je otázne (Erdélyi 2009, 184-203). Ved’ práve v tomto období vrcholili zbožné odkazy (dedičstvá), napríklad Doroty Reich z roku 1490 a spolupráca kláštora a mestskej rady bola v podstate bezproblémová, pričom mesto uvolňovalo nemalé prostriedky na prestavbu a fungovanie kláštora (Sroka 2011, 33). Práve v tomto „krízovom“ období kláštor dokonca začal budovat’ v údolí Mníchovského potoka v katastri obce Zlaté priestor pre svoju obnovu. Bol to drevený objekt, ktorý pravdepodobne slúžil ako pustovňa. Bola to jednoduchá budova $\mathrm{v}$ polohe na Kláštorisku na ploche s rozmermi 40x15 m, ktorej výstavba sa datuje do konca 15. storočia (Slivka 1998, 79).

Výrazne charitatívnou činnostou sa zaoberali augustiniáni v Kláštore sv. Alžbety v Spišskom Podhradí. Základnou bázou pre vznik tohto kláštora bol totiž mestský špitál založený niekedy okolo roku 1397 miestnym farárom Henczmanusom. Špitál bol však tak slabo obdarovaný, že traja miestni správcovia nemohli pre chudobu spravovat objekt a radšej sa svojho úradu do roku 1399 vzdali. Krátko po tom špitál prevzali augustiniáni, no bez súhlasu miestneho farára. Ten síce nebol schopný zabezpečit správcu objektu, no ani reholníkov si vo svojom meste neželal. Čo bolo príčinou tohto odmietnutia? Vzt̉ahy medzi plebánmi a mendikantmi boli väčšinou napäté, najmä do vyriešenia vzájomných finančných vztahov. Podal preto v Ostrihome stažnost', ktorú v roku 1400 prešetrila Spišská Kapitula. Obyvatelia mesta si však želali, aby špitál spravovali nadalej augustiniáni (ABÚ SK, f. HMSK, Scr. 5, f. 9, nr. 15; MNL OL DF 262 924; Wagner I 1774, 417). Dôvod neochoty miestneho farára Jána Libusza akceptovat augustiniánov vyplýva $z$ jeho dalšej stažnosti z roku 1402 adresovanej už na vyššiu inštanciu, k pápežskej kúrii v Ríme. Jednalo sa o zasahovanie do práv mestského farára, čím sa myslelo na neodvádzanie poplatkov zo štóly, ktorú dostávali augustiniáni za vysluhovanie sviatostí. Rímsky pápež Bonifác IX. (1389 - 1404) vydal 9. marca 1402 bulu, ktorou zakazoval zasahovanie do kompetencií miestneho farára. Medzi narušovatel'mi sa výslovne spomínajú žobraví bratia (mendicantium fratres) a antoniti (canonici monasterii et domorum sancti Antonii Viennensis, ordinis sancti Augustini) (MVH I/4 2000, 424425). Augustiniáni sa tu síce explicitne nespomínajú, no ako už bolo spomenuté, od roku 1399 v Spišskom Podhradí pôsobili a patrili do skupiny žobravých reholí.

Prví augustiniáni sa teda v Spišskom Podhradí usadili v drevenej budove pri kamennej kaplnke sv. Alžbety. Ich pôsobenie sa preto minimálne spočiatku spájalo s charitatívnou a so sociálnou činnostou v miestnom špitáli.

No v monumentálnom diele Monasteriologiae regni Hungariae II. sa objavuje správa o existencii vel'kého kláštora (claustrum magnum) rovnakého zasvätenia, a to aj na Spišskom hrade, čo zrejme súvisí s obrovskou rozlohou tohto hradu (Fuxhoffer - Czinár 1860, 220; Hradszky 1884, 38). Na Spišskom hrade sa skutočne nachádzala kaplnka sv. Alžbety, no o existencii kláštora na hrade nie sú hodnoverné správy. Táto informácia preto môže súvisiet’ s tým, že podhradskí augustiniáni mohli mat̉ vo svoje duchovnej správe hradnú kaplnku. Ďalšou možnostou je dočasný pobyt augustiniánov na hrade, možno v záverečnom období existencie kláštora. Po roku 1526 v Uhorsku totiž prebiehala vojna o nástupníctvo na uhorský trón a Spišská Kapitula, Spišské Podhradie a Spišský hrad mali v tomto konflikte svoje záujmy. V 16. storočí sa tak napríklad stretávame s dominikánmi, ktorí sa dočasne zdržiavali na Šarišskom hrade (DCS 1780, 556; Čižmár 1999, 13 14). Je teda možné, že podhradskí augustiniáni sa podobne dočasne mohli presídlit pod ochranu Spišského hradu.

Augustiniáni však pôsobili aj na iných miestach dnešného Slovenska mimo svojich kláštorov. Ved’ archetypom mendikanta bol aj potulný kazatel'. Nateraz o tejto činnosti neexistuje vela informácií. Táto potulná pastorácia augustiniánov priviedla napríklad do Košíc a do Banskej Bystrice. 
Už v roku 1402 sa pri pápežskej kúrii na ich činnost̉ stažoval aj košický mestský farár Štefan de Caseda, ktorý zrejme koordinoval svoju apeláciu so spišskopodhradským farárom Jánom Libuszom, pretože pápež vydal svoje listiny pre oboch v rovnaký deň 9. marca. Údajne v meste Košice dochádzalo k neporiadkom, ktorého sa dopúštali františkáni (minoriti), dominikáni a augustiniáni, čo mala prešetrit príslušná cirkevná vrchnost' (MVH I/4 2000, 423-424; Zubko 2012/13, 26; Halaga 1992, 123-124). Išlo zrejme podobne ako v Spišskom Podhradí o krátenie príjmov mestského farára za štólne poplatky. No františkáni a dominikáni už v meste mali svoje kláštory, a tak nie je jasné, prečo nemali usporiadané vzţahy s miestnym farárom. Augustiniáni však svoj kláštor v Košiciach ešte nemali. Preto krátko na to v roku 1422 generálny prior Augustín Favaroni získal súhlas krála Žigmunda Luxemburského (1387 - 1437) na založenie kláštora sv. Jána Evanjelistu a touto úlohou poveril krakovského augustiniána Izaiáša Bonera z Krakova, zvaného tiež Lechius (Bardón 1890, 406; Uth 1930, 75-76). Už viackrát spomínaný doktor svätej teológie Izaiáš Boner, je augustiniánmi uctievaný ako blahoslavený. Od roku 1428 pôsobil ako bardejovský prior, potom ako vikár bavorskej provincie a napokon v Krakove ako lektor (učitel') a profesor na Jagelovskej univerzite, kde umrel 8. februára v roku 1471 (Milensius 1613, 45-46).

Pokus o fundáciu tohto kláštora je tiež potrebné dat do kontextu prenikania reformných myšlienok hlásajúcich prísnejšie dodržiavanie Reguly sv. Augustína a augustiniánskej konštitúcie, ktoré sa do Uhorska dostávali z bavorskej provincie v prvej polovici 15. storočia (Erdélyi 2004, 128-131). V Košiciach v tomto období však už pôsobili obidve hlavné žobravé rehole, a preto miesto pre tretiu, v relatívne malom meste, nebolo. A to bol zrejme hlavný dôvod neúspechu tejto fundácie.

O okolnostiach príchodu a pôsobenia augustiniánov v Banskej Bystrici vieme najmenej. Treba povedat, že toto významné banské mesto bolo jediným „väčším“ stredovekým mestom na území dnešného Slovenska, ktoré nemalo na svojom území kláštor, no charitatívne potreby meštanov saturoval miestny špitál sv. Alžbety. Preto možno predpokladat minimálne snahu žobravých reholí usadit' sa v tomto prosperujúcom baníckom meste. No a augustiniáni boli tomuto cielu zrejme najbližšie. Pôsobili totiž pri Kaplnke sv. Archanjela Michala - neskôr sv. Kríža, v tzv. Slovenskom kostole (windische Kirche) v areáli mestského hradu, kde je ich pôsobenie doložené v odpustkovej listine z roku 1406 (Matulay 1980, 62; Ret'kovská 2010, 29).

Pastoračné potreby a spoločná reholná príslušnost̉ celkom prirodzene viedli augustiniánov k intenzívnej spolupráci. Dôležitým faktorom bola aj vzájomná geografická blízkost́. Na základe písomného materiálu možno potvrdit velmi intenzívne vzţahy medzi kláštormi, najmä medzi kláštormi vo Vel'kom Šariši a v Bardejove a medzi kláštormi v Bardejove a v Krakove. Tu treba opät zdôraznit, že kláštor v Bardejove vznikol filiáciou z Krakova a prví reholníci, ako aj priori pochádzali z Pol'ska. Tento stav trval možno len do tridsiatych rokov 15. storočia a v nasledujúcom období kontakty ochladli (Sroka 2011,31). Ku Krakovu sa však viaže jedna z posledných správ o bardejovskom kláštore z roku 1527, ked' bol bardejovský prior Matej obžalovaný krakovskými augustiniánmi, čo už bolo spomenuté vyššie (Sroka 2011, 37).

Zachovalo sa však aj niekol'ko listín, v ktorých prior kláštora sv. Stanislava vo Velkom Šariši písal bardejovskej mestskej rade vo veci ich augustiniánskeho kláštora (DCS 1780, 547 a 552). To neznamená, že Velkošarišský kláštor zastával nejaké významnejšie postavenie, alebo že by mu patrilo vedúce miesto medzi štyrmi priorátmi. Na to neexistujú žiadne dôkazy, aj ked’ to nie je vylúčené. Bol to predsa len najstarší augustiniánsky kláštor. Možno však predpokladat, že podobné listiny si písali priori navzájom, no zachovali sa len listy z Vel'kého Šariša do Bardejova. Navyše jeden z nich z roku 1516 písal vel'košarišský prior Štefan, ako uhorský provinciál (DCS 1780, 547). No zaujímavý je list z roku 1528, v ktorom vel'košarišský prior Matúš zdôrazňuje vzájomnú úzku prepojenost' oboch kláštorov. Pripomenul, že aj on, alebo lepšie kláštor vo Velkom Šariši, mal podiel na budovaní majetku bardejovských augustiniánov, a to nielen kláštorného objektu, ale aj 
rybníka, na ktorý sa, okrem iného, skladali aj jednoduchí ludia (DCS 1780, 550-551). Existuje však aj ojedinelá správa o opačnom kontakte, a to z roku 1441, ked' bolo z Bardejova do Velkého Šariša poslané hrubé súkno v sume 450 denárov (Féjerpataky 1885, 527). Je možné, že sa jednalo o látku na odev pre reholníkov.

O kontaktoch medzi kláštormi sv. Stanislava a sv. Ducha v Hrabkove vypovedá jedine zakladacia listina z roku 1334. Fundácie Hrabkovského kláštora sa zúčastnil aj Herke z Vel'kého Šariša. Nespomína sa jeho funkcia, no možno predpokladat', že sa jednalo o priora. V prípade tohto vztahu môžeme hovorit’ o filiácii. Pri Hrabkovskom kláštore je možné doložit aj kontakty so Spišským Podhradím. Ked’ sa totiž v roku 1461 obnovil spor o jednu štvrtinu desiatkov z dediny Chmiňany pred Spišskou Kapitulou, ktorá spor riešila, Hrabkovský prior Ján si prizval aj svojho Spišskopodhradského „kolegu“ priora Štefana (MNL OL DL, 70259; Rábik 2006, 113).

Kláštory žobravých reholí zohrali významnú úlohu pri kultúrnom, spoločenskom, no najmä náboženskom živote spoločnosti predovšetkým v mestách. V stredoveku mali nezastupitelné miesto pri „kultivácii“ stredovekého človeka. Svoje miesto pôsobenia si hladali aj augustiniáni, ktorí prichádzajú relatívne neskoro, ked’ už dôležité mestá boli „obsadené“ františkánmi a dominikánmi. No aj napriek tomu sa im podarilo vytvorit pomerne kompaktné územie na Spiši a v Šariši, kde sa vzdialenosti medzi jednotlivými priorátmi pohybovali najviac v dĺžke jednodňového pochodu (cca do $30 \mathrm{~km}$ ). Všetky štyri kláštory boli z pohladu svojho poslania a zamerania čímsi výnimočné. $\mathrm{V}$ prvom rade to iste bola pastorácia a šírenie evanjelia prostredníctvom kázania a vysluhovania sviatostí. Stažnosti mestských farárov v Spišskom Podhradí a v Košiciach na ich činnost’ sú velavravné. Na tento účel si bardejovskí augustiniáni zriadili aj spolok zasvätený Božej Matke. Reholníci vo Vel'kom Šariši sa zasa, okrem iných činností, venovali aj administratívnej a notárskej práci, kedže kláštor stál v centre župy a možno v určitom období vlastnil aj autentickú pečat. Pri hrabkovských a bardejovských augustiniánoch treba zobrat do úvahy aj misijné poslanie pri konverzii pravoslávnych obyvatelov Haliče alebo Valachov, ktorí v tomto období začínajú osídlovat’ horské oblasti dnešného Slovenska. Charitatívnej a sociálnej činnosti sa venovali augustiniáni v Kláštore sv. Alžbety v Spišskom Podhradí. Miestny špitál bol neobsadený a vel'mi chudobne obdarený. Reholníci tak predstavovali pre miestnu komunitu jedinú možnost', ako tento špitál prevádzkovat. Nevedno však, ako dlho špitál fungoval, kedže v roku 1442 sa objekt spomína ako kláštor, čo však nevylučuje existenciu špitála. Augustiniáni v rámci pastorácie zrejme zavítali aj na iné miesta, pričom sa zachovali správy o ich pôsobení v Košiciach, Banskej Bystrici alebo teoreticky na Spišskom hrade. Z pohladu filiácie možno rozpoznat počiatočný vztah medzi kláštormi vo Vel'kom Šariši a Hrabkove. Pôvod rehol'níkov v kláštore v Spišskom Podhradí sa nedá presvedčivo dokázat', no asi nebudeme d’aleko od pravdy, ked' pripustíme kontakty na Hrabkovský (26 - $30 \mathrm{~km})$ alebo Vel'košarišský kláštor $(40$ - $60 \mathrm{~km})$, ktoré sú vzdialené len niekol'ko kilometrov. Pri kláštore v Bardejove môžeme celkom bezpečne hovorit’ o filiácii z Kláštora sv. Kataríny v Krakove.

\section{REFERENCES}

ABÚ SK, f. HMSK. Archív Biskupského úradu Spišská Kapitula, fond Hodnoverné miesto Spišská Kapitula (dalej ABÚ SK, f. HMSK), Scr. 5, f. 9, nr. 15.

Andrews, Frances. 2006. The Other Friers : The Carmelite, Augustinian, Sack and Pied Friers in the Middle Ages. Woodbridge.

AO II. 1881. Nagy, Imre (ed.). Codex diplomaticus hungaricus andegavensis. Anjoukori okmánytár,

Tomus II. Budapest. 
AO VI. 1891. Nagy, Imre (ed.). Codex diplomaticus hungaricus andegavensis 1353 - 1357. Anjoukori okmánytár, Tomus VI. Budapest.

Arbesmann, Rudolph. 1966. A Legendary of Early Augustinian Saints. In Analecta Augustiniana 29, 5-58.

Bardón, Lopez (ed.). 1890. Nicolai Crusenii Ord. S, Augustini. Pars tertia Monastici Augustiniani, Complectens epitiomen historicam FF. Augustinensium a magna Ordinis unione usque ad an. 1620, cum additamentis Revmi. P. M. Fr. Josephi Lanteri, ejusdem Ordinis, Tomus I. Vallisoleti. Beňko, Ján. 1985. Osídlenie severného Slovenska. Košice.

BV III. 1999. Bartholomaei Veneti, OSA. Registrum generalatus 1389-1393, Tomus III. Ed. Arnulfus Hartmann, Romae.

$C D H$ V/2. 1829. Fejér, Georgius (ed.). Codex diplomaticus Hungariae ecclesiasticus ac civilis : Studio et opera Georgii Fejér, Tomus V/2. Budae.

$C D H$ V/3. 1830. Fejér, Georgius (ed.). Codex diplomaticus Hungariae ecclesiasticus ac civilis : Studio et opera Georgii Fejér, Tomus V/3. Budae.

CDH VIII/4. 1832. Fejér, Georgius (ed.). Codex diplomaticus Hungariae ecclesiasticus ac civilis : Studio et opera Georgii Fejér, Tomus VIII/4. Budae.

Čižmár, Marián. 1999. Starobylý a pútnický Velký Šariš. Levoča.

DCS 1780. Wagner, Carolus (ed.). Diplomatarium comitatus Sarosiensis, quod ex tabulariis et codicibus manuscriptis eruit Carolus Wagner Hungarus zboroviensis bibliothecae universitatis regiae Budensis custod. Posonii; Cassoviae.

Domenová, Marcela. 2006a. K stavu a charakteru stredovekých testamentov v Bardejove. In Slančová, Daniela - Žarnovská Iveta (eds.). 2. študentská vedecká konferencia (zborník príspevkov). Prešov, 169-210.

Domenová, Marcela. 2006b. Stredoveké testamenty v Bardejove. In Historica Carpatica 37, 15-25. Elm, Kaspar. 1962. Beiträge zur Geschichte des Wilhelmtenordens. Köln, Graz.

Empoli, Lorenzo (ed.). 1628. Bullarium ordinis Eremitarum S. Augustini. Rome.

Erdélyi, Gabriella. 2004. Crisis or Revival? The Hungarian Province of the Order of Augustinian Friars in the Late Middle Ages. In Analecta Augustiniana 67, 117-140.

Erdélyi, Gabriella. 2009. Tales of immoral friars: morality and religion in an early sixteenth-century Hungarian town. In Social History 34/2, 184-203.

Féjerpataky, László (ed.) 1885. Magyarországi városok régi számadáskönyvei. Budapest.

Friemar de, Enrico. 1909-1912. De Origine et Progressu Ordinis Fratrum Eremitarum S. Augustini et Vero ac Proprio Titulo Eiusdem. In Analecta Augustiniana III/IV, 12. http://www.ghirardacci.org/files/biblioteca/defriemar.pdf

Fuxhoffer, Damiáni - Czinár, Maurus. 1860. Monasteriologiae regni Hungariae, Tomus II. Pestini. Halaga, R. Ondrej. 1992. Počiatky Košíc a zrod metropoly. Košice.

Hradszky, Jószef. 1884. Várdorlások a Szepességen : Szepesvár és környéke. Igló.

Hudáček, Pavol - Uličný, Ferdinand ml. 2010. Velký Šariš. In Štefánik, Martin - Lukačka, Ján (eds.). Lexikón stredovekých miest Slovenska. Bratislava, 552-563.

Hutka, Miroslav. 2012. Vitus Pannonius, egy kevéssé ismert magyarországi középkori szent. In Magyar Sion új folyam 6 (98), 203-216.

Hutka, Miroslav. 2016. Intelektuálna a vzdelanostná úroveň uhorských augustiniánov v stredoveku. In Kultúrne dejiny 7/Supplement, 19-30.

Hutka, Miroslav. 2013a. Počiatky pustovníkov sv. Augustína vo Velkom Šariši. In Historický časopis $61 / 1,143-158$.

Hutka, Miroslav. 2013b. Uhorskí augustiniáni v historickej a literárnej spisbe (s prihliadnutím na územie Slovenska). In Kultúrne dejiny 4/2, 190-206. 
Jankovič, Vendelín. 1975. Neskorý feudalizmus a jeho kríza pred buržoáznou revolúciou. In Dejiny Bardejova. Košice.

Lujik, van Benignus (ed.). 1964. Bullarium Ordinis Eremitarum S. Augustini 1187-1256. Würzburg. Matulay, Ctibor (ed.). 1980. Mesto Banská Bystrica : Katalóg administratívnych a súdnych písomností I. (1020) 1255 - 1536. Bratislava.

MES II. 1882. Knauz, Ferdinandus (ed.). Monumenta Ecclesiae Strigoniensis, Tomus II. Strigonii. Milensius, Felix. 1613. Alphabetum felicis Mliensii de monarchis \& monasteris Germaniae ac Sarmatiae citerioris ordinis eremitarum S. Augustini. Praga.

MNL OL DL. Magyar Nemzeti Levéltár Országos Levéltár, Diplomatikai Levéltár (d’alej MNL OL DL), 71270.

MVH I/4. 2000. Várszegi, Asztrik (ed.). Monumenta Vaticana historiam regni Hungariae Illustrantia 1/4 (dalej MVH). Budapest.

MVS II/1. 2009. Rábik, Vladimír (ed.). Monumenta Vaticana Slovaciae, Tomus II/1 (dalej MVS). Trnavae; Romae.

MZA E4. Moravský zemský archiv v Brně (d’alej MZA), fond Augustiniáni Brno, E 4 (d’alej E4), inv. č. 5, sign. $41 \mathrm{~V}: 1$. Dostupné online na www.monasterium.net

Rábik, Vladimír. 2006. Nemecké osídlenie na území východného Slovenska v stredoveku (Šarišská župa a slovenské časti žúp Abovskej, Zemplínskej a Užskej). Bratislava.

RDSl II. 1987. Sedlák, Vincent (ed.). Regesta diplomatica nec non epistularia Slovaciae, Tomus II. Bratislava.

Retkovská, Adriana. 2010. Rehola antonitov na Slovensku. In Acta historica Neosoliensia 13/1-2, 29.

Romhányi, Beatrix. 2000. Kolostorok és tarsaskáptalanok a középkori Magyarországon. Budapest.

Romhányi, Beatrix. 2005. Ágostonrendi remeték a középkori Magyarországon. In Aetas 20/4, 91-101.

Roth, Francis. 1953. Cardinal Richard Annibaldi First Protector of the Augustinian Order (12431276) : Chapter IV, continuation. In Augustiniana 3, 21-34.

Sedlak, Vincent (ed.). 2002. Pod vládou anjouovských králov : Pramene k dejinám Slovenska a Slovákov IV. Bratislava.

Schier, Pál Xystus - Rosnák, Martinus. 1778. Memoria provinciae Hungaricae Augustinianae antiquae, adservata in schedis P. Xysti Schier eremitae Augustiniani, ac dein per Martinum Rosnak ejusdem instituti alumnum in lucem publicam emissa Anno MDCCLXXV. Graecii.

Slivka, Michal. 1998. Stredoveké rehol’né domy na východnom Slovensku. In Zborník príspevkov k slovenským dejinám. Bratislava, 77-88.

Sopko, Július. 1980. Knižná kultúra v Bardejove pred rozšírením kníhtlače. In Kniha '77 : Zborník pre problémy a dejiny knižnej kultúry na Slovensku. Martin, 19-37.

Sroka, A. Stanisław. 2011. Bardejov v XV. storočí : štúdie z dejín mesta. Bratislava.

ŠA PO Bardejov. Štátny archív v Prešove, pobočka Bardejov, fond Magistrát mesta Bardejov (dalej ŠA PO Bardejov).

Theiner, Augustino (ed.). 1863. Vetera monumenta Slavorum meridionalium historiam illustrantia I. Rome.

Udvárdy, József. 1956. Etienne de l'Ile (†1382), Ermite de St. Augustin et archevêque de Kalocha (Hongrie). In Augustiniana 6, 322-335.

Uth, O. Grzegorz. 1930. Szkic historyczno-biograficzny Zakonu augustjańskiego w Polsce. Kraków. Vurum, Josephus. 1835. Episcopatus Nitriensis eiusque praesulum memoria : cum ichnographicis tabellis exhibentibus priorem, ac modernam faciem castri, et civitatis Nitriensis. Posonii.

Wagner I. 1774. Wagner, Carolus (ed.). Analecta Scepusii sacri et profani I. Viennae.

ZsO I. 1951. Mályusz, Elemér (ed.). Zsigmondkori oklevéltár 1387 - 1399, Tomus I. Budapest. 
Zubko, Peter. 2012/13. Kult svätej Krvi v Košiciach : rozprávanie o stratených stredovekých relikviách. Košice.

\begin{abstract}
SUMMARY: CHARISM AND THE MISSION OF MEDIEVAL AUGUSTINIAN MONASTERIES IN THE AREA OF MODERN SLOVAKIA. The monasteries of the mendicant orders played an important role in the cultural, social and particularly religious life of the medieval society, especially in cities. In the Middle Ages they had an irreplaceable place in the "cultivation" of a medieval man. Augustinians, although they arrived relatively late, when important cities had been already "occupied" by the Franciscans and Dominicans, also sought a space to carry out their work and influence. Still, they managed to create a relatively compact territory in Spiš and Šariš, where the distances between the individual priorates were the length of one-day's journey (up to $30 \mathrm{~km}$ ) at most. All four monasteries were somewhat exceptional in terms of their mission and focus. First of all, there was the pastoral work and the spreading of the Gospel through preaching and celebrating the sacraments; the complaints of the town priests in Spišské Podhradie and Košice about their activities speak volumes. For this purpose, the Augustinians of Bardejov also established a lay association dedicated to the Mother of God. The monks in Velký Šariš devoted themselves, among other activities, to administrative and notary work, since the monastery was located in the centre of the county and it may have even owned an authentic seal. In case of the Augustinians of Hrabkov and Bardejov, it is also necessary to take into account their pastoral work in the process of the conversion of the Orthodox inhabitants of Halic or the migrants from Wallachia, who at that time began to settle the mountainous areas of modern Slovakia. The Augustinians of the St. Elizabeth monastery in Spišské Podhradie devoted themselves to charitable and social activities. The local hospital was unoccupied and very poorly endowed. Civilian administrators were not able to carry on with it because of a lack of funds. Thus, for the local community to run this hospital, the only option was the religious order. It is not known, though, how long this hospital was in operation, since in 1442 the property was described as a monastery, but this does not rule out the existence of a hospital. Apparently, Augustinians did pastoral care in other places, too, as there are records of their activities in Košice, Banská Bystrica and at Spiš Castle.
\end{abstract}

Mgr. Miroslav Hutka, PhD.

Catholic University of Ružomberok

Faculty of Arts and Letters

Department of History

Hrabovská cesta 1B

03401 Ružomberok

Slovakia

miroslav.hutka@ku.sk 